\title{
Strengthening teacher trainers' ICT competencies through ICT design teams: lessons learned
}

\author{
Bram Pynoo \\ Educational Science, Vrije Universiteit Brussel, Belgium
}

\begin{abstract}
In order for teacher trainers to effectively integrate ICT in their teaching practice and serve as a model to their pre-service teachers, teacher training should consist of technological, pedagogical and content knowledge. One way to achieve this is by setting up collaborative (design) teams. In this contribution four cases of ICT design teams are presented, each starting from a different perspective. The functioning of the design teams is assessed by making use of two recently developed frameworks. The team leaders are vital for the functioning of their team, and all teams succeed (at least to some extent) in designing learning materials and strengthening the ICT competences of the team members. Other success factors are the networked nature of the design teams and the personal interest of the team members; whereas time and duration of the project were the limiting factors. The project ran over two academic years; limiting the activities of the design team to one school-year might have led to fewer drop-outs and more involvement.
\end{abstract}

Key words: teacher training, ICT-competencies, community of practice, blended learning, ICT design team

\section{Introduction}

During the school-year 2007-2008 formal ICT objectives were introduced in Flem ish primary education. This (r)evolution was however not supported by a definition of ICTrelated qualifications for (future) teachers. This ultimately led to a situation in which teachers' ICT use and ICT competences (in primary and secondary school) remain at a low level (Pynoo, et al., 2013). Surprisingly, these findings are also observed in the youngest group of teachers (= younger than $33 \mathrm{y}$ ).

Teacher trainers hold the key to developing the ICT competences of pre-service teachers, hereby applying the theorem "teach as you preach". To that end they should possess the necessary ICT competences, as described in the Flemish ICT Development Profile for Teacher Educators which was developed following a review of the literature and existing frameworks (see Tondeur, Aesaert, Pynoo, van Braak, Fraeyman \& Erstad, 20I7). According to TPACK (Mishra \& Koehler, 2006), teachers should combine technological, pedagogical and content knowledge in order to effectively integrate ICT into their teaching practice. One way to achieve this, and implement this development pro- 
file in practice is by setting up design teams (Becuwe, Tondeur, Pareja Roblin, Thys \& Castelein, 20I6; Tondeur, Becuwe, Pareja Roblin, Castelein \& Thys, 2015).

Collaborative initiatives are among the most effective strategies for teacher professional development programs (Avalos, 20II; Binkhorst et al., 20I5; Crow \& Pounder, 2000; van Veen, 20I0). Several types of collaboration/communities exist. In Lesson Study - a practice in use since the I870s in Japan (Dudley, 2013) - the aim is to improve aspects of the learning of pupils. A group of teachers analyzes a lesson or an aspect of that lesson in order to redesign it based upon available evidence of what worked (else)where. The redesigned lesson is then put into practice and the group members monitor and analyze pupils' reactions in order to further refine the redesigned lesson. Professional learning communities (PLCs) are a different kind of community that can be defined as 'a group of teachers focused on collaborative learning by sharing experiences and critical reflection' (Brinkhorst et al., 2015). Stoll, Bolam, McMahon, Wallace and Thomas (2006) provide an overview of professional learning communities, and the factors that contribute to their success. Teacher Design Teams (TDTs) are a specific kind of PLCs targeted at developing curriculum materials. Handelsatz (2009) defines a TDT as 'a group of at least two teachers, from the same or related subjects, working together on a regular basis, with the goal to (re)design and enact (a part of) their common curriculum'. TDTs are a powerful method to improve and innovate education, both from the perspective of teacher professionalization as of educational innovation.

Here, the introduction of networked ICT Design Teams is studied. An ICT Design Team (IDT) is a specific type of TDT targeted at strengthening members' ICT competences (Stoll, et al., 2006) while developing ICT-based or - enriched learning activities or curriculum materials. Networked refers to team members of different institutions. In view of the study setting - a network of teacher training institutions - IDTs are operationalized here as 'teams of (teacher) trainers, lecturers and ICT experts from at least three institutions who go collaboratively through a design process in order to deliver a qualitative end product'. In this contribution four networked IDT cases - each starting from a different perspective - are described.

\section{Conditions for successful design teams}

Two recently developed frameworks are used as a reference to evaluate the effects and extent of success of the ICT design teams. First, Brinkhorst et al. (2015) proposed and validated a conceptual framework for TDTs. Their framework consists of different factors that contribute to TDTs that are distributed over three stages (input, process and outcome). At the input stage, individual (motivation, experience, ambitions) and contextual (schools' ambitions, support and involvement) characteristics are outlined. Next, at the process level; five factors are discerned with the team leader as key person to structure, organize and guide the team interactions during and outside the (activities of the) design team and direct the team towards a specific goal (there should be coherence between the individual, team and project goals). A fifth factor at process level concerns the organization of the design team in which team composition and time may vary depending on the design team. 
In terms of effectivity the composition of an ideal team is "... small enough to know everyone in the team and large enough to bring a variety of knowledge and ideas into the team" (Thousand \& Villa, I993, in Brinkhorst et al., 2015). Time may refer to the time team members invest in the activities of the design team, but also to the time provided by the institution to invest in design team activities. Finally, at the outcome level, Brinkhorst et al. (2015) take professional development, and the designed material(s) into account. To evaluate professional development, the levels of Guskey (2002) may be used: (I) Participants' reaction; (2) Participants' learning; (3) Change in practice (Brinkhorst et al., 20I5); (4) Participants' use of new knowledge; (5) Student learning outcomes.

Second, Becuwe, Pareja Roblin, Tondeur, Thys, Castelein, and Voogt (2017) provide - through a Delphi study - an overview of the conditions that need to be taken into account for successfully implementing a TDT, at the level of the team and the institution. They stress that factors at the institutional level affect the team level; such that an innovative institutional culture will be reflected in the innovative character of the design task and approach of the TDT (Becuwe et al., 20I7). At team level, the conditions for setting up successful TDTs can be grouped into four themes: the design task (long-term view; consisting of technological, pedagogical and content components); team composition (team members are open to innovation, trust each other, and are open to feedback); collaboration (members feel responsible for the design task and results); and role of the coach (flexible and adapts to needs of the members). At the institutional level, the role of the institution (being supportive for TDTs) and structural issues (give team members and the coach time to participate) (Becuwe et al., 20I7).

As these conditions identified by Becuwe et al. (2017) elaborate on the factors at play in the input stage of the framework of Brinkhorst et al. (2015), these frameworks are integrated into the conceptual framework for analyzing the ICT Design Teams of this study (see Figure I). The design task - important for Becuwe et al. (2017) but missing in the framework of Brinkhorst et al. (2015) is integrated into the team characteristics. 


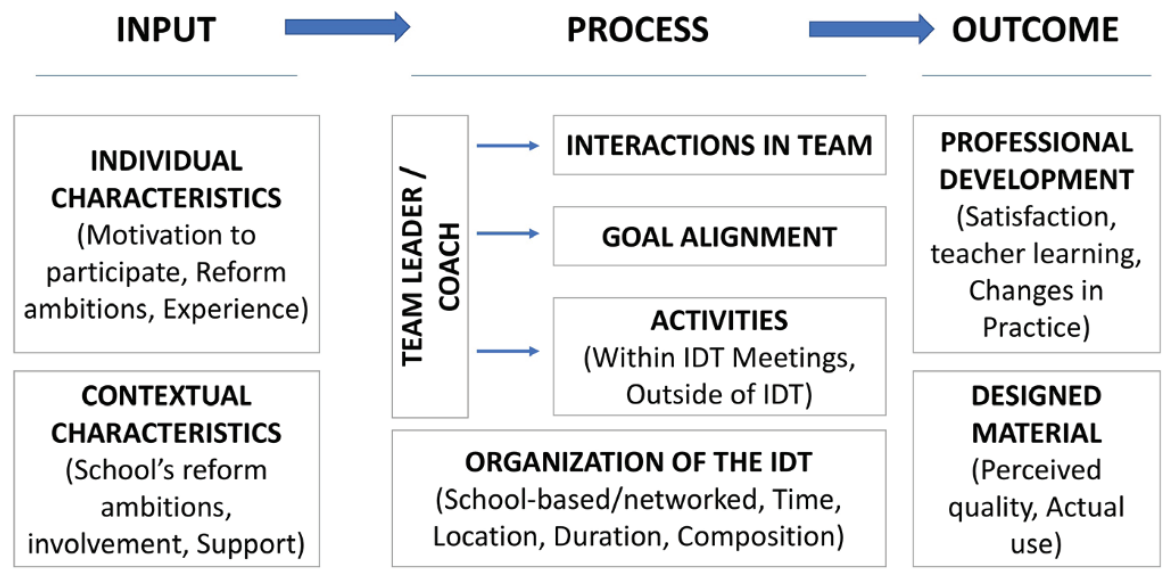

Figure 1: Conceptual framework for describing and analyzing ICT Design Teams - adapted from Brinkhorst et al. (2015) and Becuwe et al. (2017).

\section{Methodology}

In this study, the factors that contribute to the success of IDTs in designing ICT supported learning materials and building IDT members' ICT competencies are investigated. For this aim, the trajectories of the different IDTs are scrutinized, from startup to delivery in order to provide guidelines for implementing IDTs. Data were gathered through observations, document analysis (project proposals, meeting minutes and reports) and meetings with the team leaders (or coaches) of the different teams. In order to analyze the different IDTs, the framework as depicted in Figure I will be utilized.

\subsection{Study setting}

From 2007 to 2015, four expertise networks and one regional platform of teacher training institutions existed in Flanders (the Dutch speaking part of Belgium). Each expertise network was associated with a different university and consisted of the teacher training departments of the university, and associated university colleges and Centers for Adult Education. These expertise networks were funded by the Flemish department of education and served to foster the professionalization of and collaboration between teacher trainers. This study was part of a larger project on developing ICT competences of teacher trainers under the responsibility of the expertise network associated to Ghent University (ENW AUGent). In the first phase (2012-I3) of the project an ICT competency profile for teacher trainers was developed (Tondeur et al., 20I7) which was put into practice in the second phase of the project (20I4-I5). The minister of Education decided at the end of 2014 to shut down the expertise networks by the end of 2015 . 


\section{Input}

4.1. Contextual characteristics

Prior to the call for proposals, the steering committee of the ENW AUGent prioritized four topics / study areas: Science (or STEM - Science, Technology, Engineering and Mathematics), Modern Foreign Languages, Arts \& Culture, and Blended Learning. Possible team leaders or coaches of an ICT Design Team were identified and contacted by their respective department heads to seek collaborations within the partners of the ENW AU Gent and write a project proposal in order to receive funding for their ICT Design Teams.

This resulted in four ICT Design Teams (see Table I for an overview) each departing from a different perspective:

- Team I: Blended Learning. The project of this team is based on the assessment that teachers are willing to redesign their courses as part of blended learning, but that they are requesting support in this matter. The objective of this project is, first of all, to develop an action plan for the redesign of a 'classic' course to a 'blended' course and then to concretize this action plan by offering an overview regarding a variety of ICT applications. To that end, a community of practice is set-up.

=>perspective: top down; department heads who oblige their teachers to adopt a new of teaching.

- Team 2: Language Didactics. This teams departs from a specific domain and aims to develop learning materials that can be applied in a context of "Flipping the classroom" in order to achieve meaningful didactics for modern foreign languages. They will adopt the Model of Gerstein (Gerstein, 20II) during their development cycle. The first objective of their project is to develop material; a second objective is to introduce this material.

=> perspective: top-down a department (head) that decides to blend the program

- Team 3: Arts and Culture. The objective of the design team is to strengthen the ICT and media skills of the teacher trainers of the involved partner institutions in their pedagogical practice of Art and Culture courses. To this end, a project is being developed around 'Street Art in Ghent' where participants have to collect information about street art in Ghent by means of various ICT tools.

=> perspective: bottom-up; outcome driven; digitizing with a specific goal in mind 
- Team 4: Smart Science. The project of this team is based on the problem "How can teacher trainers stimulate and support teachers (future ones and currently in the work field) to allow mobile devices find their way into the classroom (as supporting means) by creating a powerful learning environment that facilitates inspiring knowledge education?" To this end, a 'community of practice' will be established to develop and disseminate good practices on the one hand; a manual will be developed that will be aimed at teacher trainers who are actively involved in knowledge education on the other hand. As a result of this project, other initiatives will also be established for further professionalization of teacher trainers and teachers.

=> perspective: bottom-up; technology driven

\begin{tabular}{|c|c|c|c|c|}
\hline Team & $\mathbf{I}$ & 2 & 3 & 4 \\
\hline Topic / Area & Blended learning & $\begin{array}{l}\text { Modern Foreign } \\
\text { Languages }\end{array}$ & Arts \& Culture & Science / STEM \\
\hline $\begin{array}{l}\text { Team } \\
\text { composition }\end{array}$ & $\begin{array}{l}\text { I2 ICT-experts } \\
\text { and program } \\
\text { coordinators from } \\
8 \text { institutions }\end{array}$ & $\begin{array}{l}6 \text { language } \\
\text { lecturers and I } \\
\text { ICT-expert from } 5 \\
\text { institutions }\end{array}$ & $\begin{array}{l}8 \text { ICT-competent } \\
\text { and less competent } \\
\text { lecturers from three } \\
\text { institutions }\end{array}$ & $\begin{array}{l}8 \text { lecturers with } \\
\text { strong ICT } \\
\text { competences from } 5 \\
\text { institutions }\end{array}$ \\
\hline $\begin{array}{l}\text { Aim: } \\
\text { to develop ... }\end{array}$ & $\begin{array}{l}\text {... a roadmap for } \\
\text { blended learning }\end{array}$ & $\begin{array}{l}\text {... flipped } \\
\text { classroom learning } \\
\text { activities }\end{array}$ & $\begin{array}{l}\text {... a street art route } \\
\text { in Ghent (Belgium) }\end{array}$ & $\begin{array}{l}\text {... different types of } \\
\text { knowledge clips }\end{array}$ \\
\hline Methodology & $\begin{array}{l}\text { Community of } \\
\text { Practice }\end{array}$ & ADDIE & Project & $\begin{array}{l}\text { Design based } \\
\text { research }\end{array}$ \\
\hline Duration & \multicolumn{4}{|c|}{ April Ist 2014 until August 3Ist 2015} \\
\hline Time/Funding & \multicolumn{4}{|c|}{$\begin{array}{l}\text { Io.ooo euro to partly fund appointment of the team leader (approx. } 5 \% \text { ) and activities of } \\
\text { the IDT. Participation of team members on voluntary grounds }\end{array}$} \\
\hline
\end{tabular}

Table 1: Characteristics of the four ICT design teams - input level.

\subsection{Individual/team characteristics}

Departing from the definition of Teacher Design Teams of Handelsatz (2009), IDTs are operationalized here as 'teams of (teacher)trainers, lecturers and ICT-experts from at least three institutions who go collaboratively through a design process in order to deliver a qualitative end product'. While going through this design cycle, team members professionalize themselves and strengthen their ICT competences. The team composition was similar in teams 2 , 3 and 4 being teacher trainers who teach in the topic of the design team; whereas team I consisted mainly of ICT-experts (who support the teacher trainers at their own institution) and program coordinators.

In order to get an overview of the competencies related to the use of ICT and attitudes towards the use of ICT, a survey was conducted among the ICT Design Team members. The following constructs were measured:

- Technology acceptance: attitude, perceived usefulness and perceived ease of use (Davis, 1989) anchored between I: fully disagree and 6: fully agree. 
- ICT competencies: Self-reported, to use ICT to support lessons, and to use ICT as a model for student teachers (Pynoo, et al., 20I3; Tondeur et al., 20I7) anchored between I: fully disagree and 6: fully agree.

- ICT Infrastructure: at one's own institution, and in the training institutions anchored between I: fully disagree and 6: fully agree.

- 2nd order didactics: scale derived from the ICT-competency profile of teacher trainers (see Tondeur et al., 20I7) anchored between I: fully disagree and 6: fully agree.

The results of the questionnaire can be found in Table 2. The sample was too small to perform statistical tests. However, the results are an indication of the competencies of the team members. Overall, team members accept technology, and feel moderately competent in using ICT for different purposes. Members of team I use ICT more frequently than the members of other teams, both for professional and leisure reasons, which might be attributed to their role in their institution (ICT-expert or program leader), and their expertise in using ICT. Perceptions of ICT infrastructure show that teacher trainers estimate that the facilities at their institution are better than at the internship institutions which is congruent with the findings of the ICT-monitor in secondary education (Pynoo et al., 2013). 


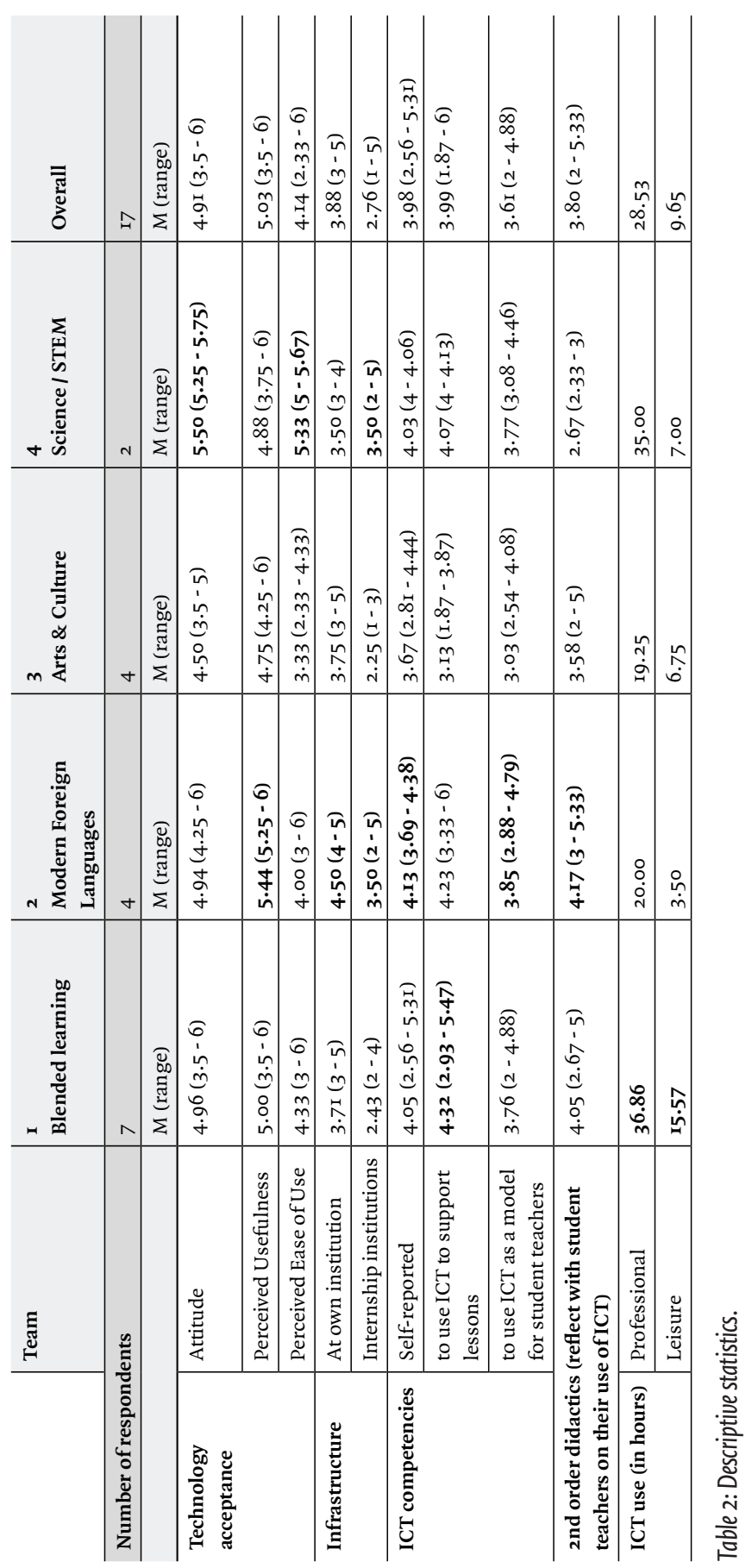




\section{Process}

At the level of the project, teams were expected to meet on a regular basis, share information and expertise, and develop qualitative materials. In terms of professional development, it was expected that the IDT would strengthen the ICT competencies of the team members. Below, the process is discussed per ICT design team; a summary is provided in Table 3 .

\begin{tabular}{|c|c|c|c|c|}
\hline & Team I & Team 2 & Team $_{3}$ & Team 4 \\
\hline Topic/area & Blended learning & $\begin{array}{l}\text { Modern Foreign } \\
\text { Languages }\end{array}$ & Arts \& Culture & Science / STEM \\
\hline Team leader/coach & $\begin{array}{l}\text { Very (pro-)active, } \\
\text { takes action to } \\
\text { engage all team } \\
\text { members }\end{array}$ & $\begin{array}{l}\text { Team leader heavily } \\
\text { relying on ICT- } \\
\text { expert (coach) }\end{array}$ & $\begin{array}{l}3 \text { team leaders act } \\
\text { as design team and } \\
\text { design \& guide } \\
\text { learning activities }\end{array}$ & $\begin{array}{l}\text { Strong } \\
\text { engagement, } \\
\text { builds on informal } \\
\text { contacts }\end{array}$ \\
\hline $\begin{array}{l}\text { Interactions } \\
\text { in team }\end{array}$ & $\begin{array}{l}\text { Core and } \\
\text { occasional } \\
\text { members. }\end{array}$ & $\begin{array}{l}\text { Members were very } \\
\text { committed }\end{array}$ & $\begin{array}{l}\text { Drop-out (not } \\
\text { much actions } \\
\text { undertaken to re- } \\
\text { engage dropped- } \\
\text { out members) }\end{array}$ & $\begin{array}{l}\text { Initially very } \\
\text { committed }\end{array}$ \\
\hline Goal & $\begin{array}{l}\text { A website with } \\
\text { roadmap and good } \\
\text { practices }\end{array}$ & $\begin{array}{l}\text { Diverse learning } \\
\text { activities tested in a } \\
\text { classroom context }\end{array}$ & $\begin{array}{l}\text { Street art in Ghent } \\
\text { route \& website }\end{array}$ & $\begin{array}{l}\text { Diverse clips and } \\
\text { manuals, tested } \\
\text { with students in } \\
\text { teacher education }\end{array}$ \\
\hline Activities & $\begin{array}{l}\text { Different CoPs, } \\
\text { agenda setting in } \\
\text { CoPI }\end{array}$ & $\begin{array}{l}\text { Introductory } \\
\text { workshops by in- } \\
\text { group expert, small } \\
\text { group counselling, } \\
\text { big group fine- } \\
\text { tuning }\end{array}$ & $\begin{array}{l}\text { Workshops (by } \\
\text { team leaders and } \\
\text { external expert) } \\
\text { targeted at } \\
\text { different aspects of } \\
\text { the route }\end{array}$ & $\begin{array}{l}\text { Introductory } \\
\text { workshop by } \\
\text { external expert, } \\
\text { small group } \\
\text { working sessions, } \\
\text { informal meetings }\end{array}$ \\
\hline $\begin{array}{l}\text { Organization of } \\
\text { the IDT }\end{array}$ & \multicolumn{4}{|c|}{$\begin{array}{l}\text { From April ist } 2014 \text { to August } 3 \text { Ist 20I5. Team leaders are funded } 5 \% \text { to participate, } \\
\text { team members participate voluntarily. Design teams are networked, consisting of } \\
\text { members of at least three institutions. }\end{array}$} \\
\hline
\end{tabular}

Table 3: Characteristics of the four ICT design teams - Process level.

\subsection{Team 1 - Blended learning}

Team I aimed to develop a roadmap for blended learning supported by practice examples. To achieve this, the team leader opted for the Community of Practice (CoP) methodology. Starting principles of the CoP are: (I) to learn from each other: maximal sharing of expertise; (2) teach as you preach: practice examples are collected online and discussed face to face hereby using a number of tools; and (3) double learning experience: sharing a practice example through filling out a template, is also a learning experience for the contributor. To structure the process, the method of 'the learning design studio' was applied, a method to perform practice research starting from the practice. Following this method, the team went through the following stages: 
- imagine: brainstorm on the subject and its aspects. In the course of the first CoP, the agenda for the following sessions was set resulting in a learning agenda;

- investigate: redefine the envisaged targets/results based on context-analysis. Discussion in the second $\mathrm{CoP}$ on the challenges and the presentation of the final end-product to the intended users;

- inspire: by exchanging good practices. These are collected online making use of a template;

- ideate: conceptualization of a solution: discussion of the guidelines/instruments that arise from the practice examples;

- prototype: development. Discussion and optimization of the website;

- evaluate: evaluation of the prototype. Several small-scale sessions were organized in which the website was presented to teacher trainers.

This approach was quite intensive, such that only a core group of five members attended all CoP, whereas the other members joined occasionally. The team leader maintained contact with and ensured the involvement of all team members in between the face to face sessions by regular emails. She summarized the contributions of the team members applying the principles of the CoP (teach as you preach, learn from each other). She also developed the website (http://designteamblendedleren.weebly.com [in Dutch], English version through www.ictdesignteams.be).

\subsection{Team 2 - Modern foreign languages}

This team appointed both a team leader (a language didactics teacher trainer) and a team coach (the ICT coordinator). The team leader mainly took responsibility for the administrative aspects of the design team, whereas the team coach took up the role of ICT expert. The focus of this team was first on strengthening the ICT competencies of the team members in order to (re)design curriculum materials at a later phase. The activities of this team were phased as outlined below:

Divergent phase:

- Professional development: Three exploratory ICT workshops; followed by online support of the ICT expert

- Design of curriculum materials: brainstorm sessions in groups of 4 led by the ICT expert in order to design and set-up one's own project. The following projects were set up:

- Strengthening media literacy through blogging

- Skype to cross the language boundary

- Edmodo in secondary adult education Italian

- Blogging throughout the education (learning line + coding system)

- A CoP about the noun

- Language and practice teachers learn from each other

- Development of a prototype

Convergent phase:

- Professional development in dialogue: synergetic session in which the team 
members exchanged their experiences while developing (and testing in some cases) the prototypes. The first three projects (see above) were also tested in practice by a team member.

Divergent phase:

- Implementation and evaluation of the curriculum materials: this phase was not reached during the project period.

The team coach prepared and organized all meetings in close collaboration with the ICT expert. In between sessions, several ICT tools were used to communicate with the team members. Throughout the project, there was strong commitment of the team members, both during the meetings and in between sessions. Due to long-term absence of the ICT expert near the final phase of the project period, the team leader decided to stop the activities of the team although the team members wanted to continue.

\subsection{Team 3-Arts \& culture}

The arts \& culture ICT Design Team was led by three team leaders of the same institution. The final product - a street art route in Ghent - was specified from the beginning, and all activities of the team were directed towards designing this goal, without much input from the team members. The project was organized as follows:

- Start-up session: brainstorm on the topics of the planned workshops

- Workshop I: audio and video editing

- Workshop 2: social media

- Workshop 3: apps in the classroom

- Workshop 4: geocaching and QR-codes

To support the workshops, the team leaders acted as the design team and developed manuals for different tools, manuals to use in the classroom with pre-service teachers. These manuals have also been used by team members of the other teams.

This team suffered most from drop-out of the initial members. The involvement of team members was low, which may be caused by the low frequency of meetings (only five in total), little communication from the team leaders to the team members in between sessions, and also because of the fixed outcome of the team, a street art route. Next to that, several members dropped out because their tasks changed at the beginning of the new academic year in September 20I4. Therefore, the team leaders decided to open their workshops for all interested teacher trainers, and especially for their colleagues. Dropped out team members were addressed only once, and there was ample communication with the team members in between sessions. The team leaders maintained a website: (http://projectstreetartgent.weebly.com; in Dutch) as a reference.

\subsection{Team 4 - Science/STEM}

This team already existed through previous projects. The envisaged end product was left open at the beginning of the project such that team members could prioritize ideas themselves during the first meeting. As the team decided to make different kinds of knowledge clips, the team leader invited a video design expert to the first workshop. 
This team suffered most from scheduling problems. The team members were very committed, but due to the busy schedule of all members, and changed tasks of some members at the beginning of the new academic year in September 20I4, organizing plenary sessions became unfeasible. The team leader therefore adapted his strategy and opted for small-scale or one-on-one meetings. The team members shared their expertise (rather than inviting an expert) during the different working sessions.

\subsection{Process - Summary}

Networked teams had to be set-up to foster expertise sharing, and this was greatly appreciated by the team members: they could interact and exchange information with their peers and get to know the culture in a different institution. A downside of networked teams is that at least some team members need to travel, and as such need to invest more time in the activities of the design team. Significant differences were observed between the approaches of the different team leaders. All team leaders took up the administrative role - as was expected by the funding organization. The team leaders of teams I, 3 and 4 also took on the role of the coach if needed, whereas the team leader of team 2 decided to stop the activities of the team in view of the long-term absence of the coach. Different (communication) strategies were applied by the team leaders to involve the team members; the strategies were either very proactive (team I, members were informed and involved) or minimal in terms of communication (team 3, members dropped out). In team 2, communication was also minimal, but members at risk of dropping out were contacted more frequently, and there were more group sessions than in team 3. In team 4 , the team leader changed strategy: from group sessions to one-on-one sessions to keep members up-to-date and involved.

\section{Outcome}

Expected outcomes at the level of the project were on the one hand product-oriented: developing curriculum materials and supportive material; and on the other hand process-oriented: strengthening the ICT competencies of the team members. Dissemination towards other teacher training institutions/teacher trainers is also an objective. Table 4 summarizes the outcomes of the different ICT design teams.

\subsection{Designed materials}

All teams succeeded in designing or developing learning/curriculum materials. For Team 1 this was a roadmap for blended learning supported by good practices and some adjoining checklists to evaluate blended course materials. The materials (roadmap, checklists, good practices) are gathered on the project website. To finalize the project, several workshops were developed for teacher trainers to get to know and learn to work with the website. In Team 2, team members developed curriculum materials for their own practice. All team members set up a project, but only three projects resulted in a prototype that was tested in practice. Team 3 worked towards a street art route in Ghent and developed meanwhile several support materials (manuals, website) that were immediately 
tested in practice and also used by other teams. Team members participated - during the final workshop - in the first test of the street art route. Team 4 created different knowledge clips and a how-to (to create knowledge clips) that was tested in groups of pre-service teachers.

\begin{tabular}{l|l|l|l|l} 
& Team I & Team 2 & Team 3 & Team 4 \\
\hline Topic/area & Blended learning & $\begin{array}{l}\text { Modern Foreign } \\
\text { Languages }\end{array}$ & Arts \& Culture & Science / STEM \\
\hline Designed material & $\begin{array}{l}\text { A website with } \\
\text { roadmap and good } \\
\text { practices }\end{array}$ & $\begin{array}{l}\text { Diverse learning } \\
\text { activities tested in a } \\
\text { classroom context }\end{array}$ & $\begin{array}{l}\text { Street art in Ghent } \\
\text { route, manuals \& } \\
\text { website }\end{array}$ & $\begin{array}{l}\text { Diverse clips and } \\
\text { manuals, tested } \\
\text { with students in } \\
\text { teacher education }\end{array}$ \\
\hline $\begin{array}{l}\text { Professional } \\
\text { development }\end{array}$ & $\begin{array}{l}\text { Good practices } \\
\text { are shared, also } \\
\text { with the student } \\
\text { teachers, and the } \\
\text { website is used as } \\
\text { reference material }\end{array}$ & $\begin{array}{l}\text { Most team } \\
\text { members applied } \\
\text { the knowledge } \\
\text { they gained in their } \\
\text { own practice and } \\
\text { with pre-service } \\
\text { teachers }\end{array}$ & $\begin{array}{l}\text { Most team mem- } \\
\text { bers came to level } \\
\text { "participants' } \\
\text { learning" in the } \\
\text { project period. }\end{array}$ & $\begin{array}{l}\text { The team members } \\
\text { were quite ICT- } \\
\text { competent such } \\
\text { that most applied } \\
\text { the knowledge } \\
\text { gain in their } \\
\text { practice with pre- } \\
\text { service teachers. }\end{array}$ \\
\hline Evaluation & Success & $\begin{array}{l}\text { Partial success: } \\
\text { IDT stopped earlier } \\
\text { due to illness of } \\
\text { ICT-expert }\end{array}$ & $\begin{array}{l}\text { Partial success: } \\
\text { drop-out of } \\
\text { original team } \\
\text { members, } \\
\text { involvement of } \\
\text { own team }\end{array}$ & $\begin{array}{l}\text { Partial success: } \\
\text { formal large group } \\
\text { sessions replaced } \\
\text { by informal small } \\
\text { group meetings }\end{array}$ \\
\hline
\end{tabular}

Table 4: Characteristics of the four ICT Design Teams - Outcome level.

\subsection{Professional development}

Looking at professional development in terms of the levels of Guskey (2002) being (I) Participants' reaction; (2) Participants' learning; (3) Change in practice (Brinkhorst et al., 20I5); (4) Participants' use of new knowledge; (5) Student learning outcomes; it can be concluded that all teams reached at least level 2. During the closing meetings with the different IDTs, participants reflected on their development over the course of the project. Most indicated that they had been experimenting in their practice with ICT relying on the input they received during the sessions of their IDT. Most participants also planned to integrate ICT more into their practice in the next semester, in many cases inspired by practice examples provided by other members of their IDT. Change in practice (level 3) could not be observed, but several team members indicated that they applied the knowledge they gained in their practice in a different situation (level 4 ). The duration of the project was too short to also have an effect on students' learning outcomes. This could be a topic for a follow-up study. 


\section{Conclusion}

In this study the functioning of four ICT design teams that departed from different perspectives (bottom-up/top-down; technology-/content driven, etc.) in different subject areas (languages, arts \& culture, science/STEM and blended learning) was scrutinized. All four IDTs can be considered a success in terms of collaborating, exchanging (good) practices and the professionalization of the team members. On the other hand, not all teams succeeded in creating the targeted end-products and disseminating the knowledge they gained throughout the project. Factors that contributed most to the success were the team leader(s), the networked nature of the teams and personal interest (towards the outcomes: (re)designed curriculum materials and professional development) of the team members. The team leader plays a vital role in the practical organization of the team and may contribute to the involvement of the team members by contacting them regularly, or planning one-on-one sessions. By setting-up networked ICT design teams, team members could exchange information in a 'safe' environment and get to know the culture in different institutions. This was valued greatly by the team members. Finally, it should be noted that team members participated and continued to be involved from personal interest, such as professionalization needs, expectations of the institution, course redesign, autonomous motivation, and so on.

On the downside, the time and duration of the project were the most limiting factors. Team members participated on a voluntary basis, and due to the networked nature of the team some team members needed to invest much more time in the activities of the design team. The planning of the project from April 20I4 to August 2015 was also not ideal. At the start of the new academic year in September 2014, several team members dropped out because of changed tasks at their institutions.

In conclusion, the introduction of ICT design teams can be considered a success, and the methodology of networked ICT design teams is rewarding for the team members. The methodology of IDTs has a lot of potential for educational innovation in nonWestern-European contexts, for instance in African countries. A small team of educational experts (who take up the role of team leader \& coach) can guide several networked design teams. Team members of these networked IDTs also contribute knowledge \& experience; and learn from the team leaders and from the other members. The members of the networked design teams can then serve as team coaches for design teams within their own institution. This way, a small group of experts can strengthen and support an extensive group of teachers.

\section{References}

Avalos, B. (20II). Teacher professional development in Teaching and Teacher Education over ten years. Teaching and Teacher Education, 27(I), I0-20.

Becuwe, H., Pareja Roblin, N., Tondeur, J., Thys, J., Castelein, E. \& Voogt, J. (2017). Conditions for the successful implementation of teacher educator design teams for ICT integration: A Delphi study. Australasian Journal of Educational Technology, 33(2), I59-I72.

Becuwe, H., Tondeur, J., Pareja Roblin, N., Thys, J., \& Castelein, E. (20I6). Teacher design teams as a strategy for professional development: The role of the facilitator. Educational Research and Evaluation. 
Binkhorst, F., Handelsatz, A., Poortman, C.L., van Joolingen, W.R. (2015). Understanding teacher design teams - A mixed methods approach to developing a descriptive framework. Teaching and Teacher Education, 5I, 213-224.

Crow, G. M., \& Pounder, D. G. (2000). Interdisciplinary teacher teams: context, design, and process. Educational Administration Quarterly, 36(2), 216-254.

Davis, F. D. (1989). Perceived Usefulness, Perceived Ease of Use, and User Acceptance of Information Technology. Mis Quarterly, I3(3), 319-340.

Dudley, P. (2013). Teacher learning in Lesson Study: What interaction-level discourse analysis revealed about how teachers utilized imagination, tacit knowledge of teaching and fresh evidence of pupils learning, to develop practice knowledge and so enhance their pupils' learning. Teaching and Teacher Education, 34, I07-I2I.

Gerstein, J. (20II). The flipped classroom model: A full picture. Retrieved from https://usergeneratededucation. wordpress.com/20II/06/I3/the-flipped-classroom-model-a-full-picture/

Guskey, T. (2002). Does it make a difference? Educational Leadership, 59(6), 45-5I.

Handelsatz, A. (2009). Collaborative curriculum development in teacher design teams. Doctoral dissertation submitted to obtain the degree of the degree of doctor at the University of Twente.

Mishra, P., \& Koehler, M. J. (2006). Technological Pedagogical Content Knowledge: A new framework for teacher knowledge. Teachers College Record I08 (6), I0I7-I054.

Pynoo, B., Kerckaert, S., Goeman, K., Elen, J., \& van Braak, J. (2013). MICTIVO2012. Monitor voor ICTintegratie in het Vlaamse onderwijs. Eindrapport van OBPWO-project II.02. Universiteit Gent/KU Leuven / Hogeschool Universiteit Brussel. [Dutch].

Stoll, L., Bolam, R., McMahon, A., Wallace, M., \& Thomas, S. (2006). Professional learning communities: $a$ review of the literature. Journal of Educational Change, 7, 22I-258.

Thousand, J. S., \& Villa, R. A. (1993). Collaborative teams: a powerful tool to school restructuring. In R. A. Villa, J. S. Thousand, W. Steinback, \& S. Steinback (Eds.), Restructuring for caring and effective education: An administrative guide to creating heterogeneous schools (pp. 73ero8). Baltimore: Brookes Publishing.

Tondeur, J., Aesaert, K., Pynoo, B., van Braak, J., Fraeyman, N. \& Erstad, O. (2017). Developing a validated instrument to measure preservice teachers' ICT competencies: Meeting the demands of the 21st century. British Journal of Educational technology, 48(2), 462-472.

Tondeur, J., Becuwe, H., Pareja Roblin, N., Castelein, E., \& Thys, J. (2015). De ontwikkeling van teacher design teams: anders denken en anders doen. TH\&MA, 5(14), 74-76. [Dutch].

van Veen, K., Zwart, R. C., Meirink, J. A., \& Verloop, N. (2010). Professionele ontwikkeling van leraren: een reviewstudie naar effectieve kenmerken van professionaliseringsinterventies van leraren. ICLON/Expertisecentrum Leren van Docenten. 